\title{
Structure of the seabird assemblage associated with pelagic longline vessels in the southwestern Atlantic: implications for bycatch
}

\author{
Sebastián Jiménez ${ }^{1,2,3, *}$, Andrés Domingo ${ }^{1,2}$, Martin Abreu ${ }^{1}$, Alejandro Brazeiro ${ }^{3}$ \\ ${ }^{1}$ Proyecto Albatros y Petreles - Uruguay, Centro de Investigación y Conservación Marina (CICMAR), \\ Avenida Giannattasio Km 30.5. CP 15008 Canelones, Uruguay \\ ${ }^{2}$ Dirección Nacional de Recursos Acuáticos, Recursos Pelágicos, Constituyente 1497, CP 11200, Montevideo, Uruguay \\ ${ }^{3}$ Instituto de Ecología y Ciencias Ambientales, Facultad de Ciencias, Universidad de la República, Iguá 4225, CP 11400, \\ Montevideo, Uruguay
}

\begin{abstract}
The region of the southwest Atlantic influenced by the Brazil-Malvinas Confluence (BMC) is important for globally threatened species of albatross and petrel. This applies particularly to the area of the continental slope, due to the high rates of incidental catch from pelagic longliners. We analyzed the temporal variation in the seabird assemblage associated with this fishery, identified the species that make use of discards, and evaluated their interactions while foraging. During 20 commercial fishing trips between 2005 and 2008, we completed 415 bird counts and recorded behavior in 172 of these. The observed species richness ( $\geq 38$ species) is greater than that reported for any other fishery in the region and was highest from October to April, although many species in the assemblage were significantly more abundant between May and September. Only 14 species made significant use of discards, and all of these were albatrosses and petrels captured incidentally. We observed within- and between-species competition for access to discards. In general, the frequency of intraspecific competition was greater in the most abundant species, during the period of their greatest abundance. Albatrosses were more successful in interspecific competitive interactions, and we observed a dominance hierarchy related to body size. We conclude that the composition and seasonality of the seabird bycatch is determined by the spatiotemporal dynamics of the assemblage and by the observed pattern of interspecific interactions. Discards from pelagic longline fleets operating in the BMC may be an important food source for at least 8 species of globally threatened seabirds. Understanding the effect of discards on these populations could generate useful information for conservation, although reducing bycatch levels should be considered the main goal.
\end{abstract}

KEY WORDS: Pelagic longline $\cdot$ Albatross $\cdot$ Petrels $\cdot$ Conservation $\cdot$ Uruguay

\section{INTRODUCTION}

Marine front regions coincide with the highest values of marine avian diversity and abundance (Griffiths et al. 1982, Veit 1995, Acha et al. 2004, Bost et al. 2009). The southwest Atlantic Ocean is a region characterized by the confluence of the Brazilian Current and the Malvinas Current (i.e. Brazil-Malvinas Confluence, BMC), which generates numerous superficial and sub-superficial fronts (Olson et al. 1988, Goni \& Wainer 2001, Saraceno et al. 2004). The high concentration of prey species (Acha et al. 2004) and the aggregation of fisheries resources of commercial interest along these fronts leads to the overlap of 
industrial fisheries with albatross and petrel species (Veit 1995, Acha et al. 2004, Favero \& SilvaRodríguez 2005). This region sustains various fleets of pelagic longliners concentrated on the exploitation of swordfish Xiphias gladius, tunas (bigeye Thunnus obesus, yellow-fin T. albacares, and albacore $T$. alalunga), and pelagic sharks (mainly blue shark Prionace glauca; Tuck et al. 2003, Hazin et al. 2008). Although these fleets are widely distributed in the southwestern Atlantic, the greatest fishing effort is concentrated in the region of the BMC (Tuck et al. 2003). The Uruguayan commercial fishing fleet operates near the continental slope and also in international waters where a large number of foreign fleets operate (Tuck et al. 2003, Domingo et al. 2006, Hazin et al. 2008). Seabirds interact with the fishery across the entire region, but with greatest intensity near the continental slope (Jiménez et al. 2009a, 2010).

The seabird assemblage associated with the longline fishery on the continental slope of Uruguay and adjacent zones is rich in albatross and petrel species and other pelagic seabirds of the various archipelagos and islands of the Southern Hemisphere and North Atlantic (González-Solís et al. 2007, Jiménez et al. 2009b, Jiménez \& Domingo 2009, Abreu et al. 2010a,b). These include at least 11 globally Threatened species of albatrosses and petrels, and 5 Near Threatened, according to the IUCN. These include the Tristan albatross Diomedea dabbenena, considered to be Critically Endangered, and other Endangered (e.g. black-browed albatross Thalassarche melanophrys, Atlantic yellow-nosed albatross $T$. chlororhynchos, Atlantic petrel Pterodroma incerta) and Vulnerable species (e.g. wandering albatross $D$. exulans, white-chinned petrel Procellaria aequinoctialis, and spectacled petrel Procellaria conspicillata). This zone has one of the highest levels of incidental capture of albatross and petrel species across global longline fisheries, affecting many of the threatened species (Alexander et al. 1997, Jiménez et al. 2009a).

The present study describes the structure of the seabird assemblage associated with longline fisheries in the region of the Uruguayan continental slope and nearby waters located within the area influenced by the BMC. We characterized the richness and abundances of the assemblage and its temporal variation. Within our study area, periods of the year with differing pelagic longline bycatch rates were identified, one between May and November with greater captures and one between December and April with fewer captures (Jiménez et al. 2009a). In this context, we investigated whether there is a greater richness and abundance of birds during the period of greater incidental capture. We hypothesized that the seasonal variation in incidental capture is due to the increase in richness and abundance of species between autumn and spring, and the decrease in summer.

We also determined which species in the seabird assemblage make use of the fishery discards and how the species interact when foraging for these discards. The concentration of discards in a small area near the fishing vessels may resemble a zone of high prey concentration where trophic associations form, increasing the intensity of aggressive encounters. In this context of abundant, concentrated resources, interference is the most likely mechanism of competition (Maurer 1984, Ballance et al. 1997). Body size often determines the outcome of interference competition in many animal species (Persson 1985). We tested the prediction that access to discards from this fishery is determined by body size. In particular, we predicted the existence of a dominance hierarchy determined by variation in body size between seabird species. We discuss the results in the context of their implications for understanding the observed pattern of incidental capture.

\section{MATERIALS AND METHODS}

\section{Study area}

The study area included the Uruguayan continental slope (i.e. between the 200 and $3000 \mathrm{~m}$ isobaths), the north of the Argentinean continental slope (within the Common Fishery Zone of Argentina and Uruguay, ZCPAU), the external border of the continental platform (i.e. between the 100 and $200 \mathrm{~m}$ isobaths), and Uruguayan and international deep waters (i.e. beyond the $3000 \mathrm{~m}$ isobath; Fig. 1). The principal oceanographic characteristic of this zone is the occurrence of the BMC formed by the confluence of the Brazilian Current and the Malvinas Current (Olson et al. 1988, Seeliger et al. 1998, Goni \& Wainer 2001, Acha et al. 2004, Saraceno et al. 2004, Ortega \& Martínez 2007). The confluence region of these 2 currents exhibits complex movements of fronts and the simultaneous presence of warm and cold eddies. The front of the continental slope that extends from the Burdwood Bank towards the Falkland/Malvinas Islands and the Argentinean continental slope to the BMC facing Uruguay forms one of the principal frontal systems of South America (Acha et al. 2004). 


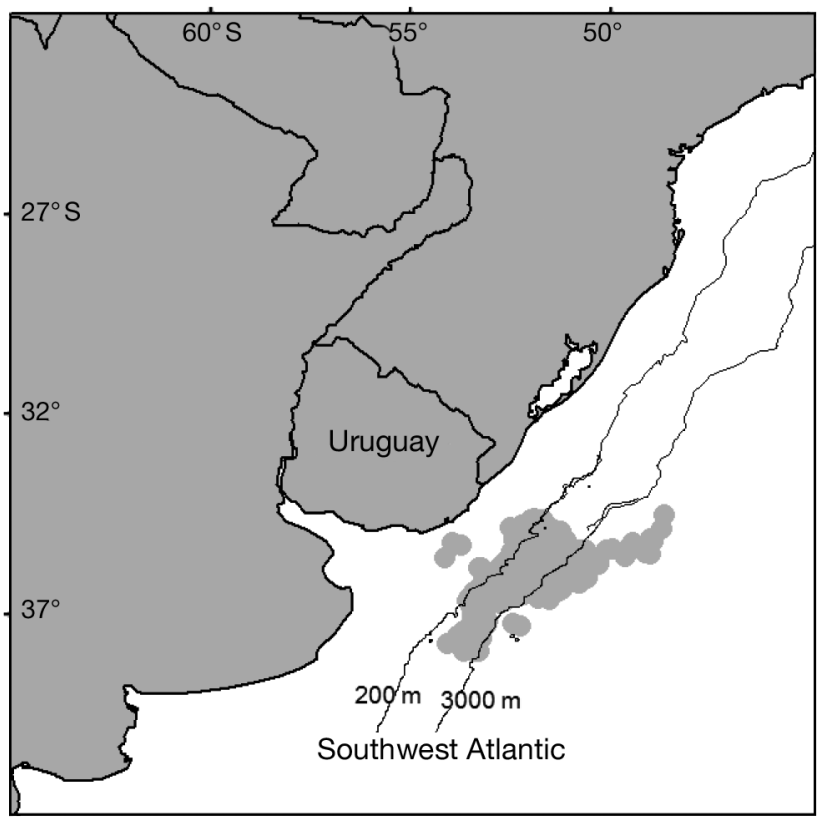

Fig. 1. Study area showing counts of seabirds associated with the longline fishery during 2005 to 2008 ( $\mathrm{n}=415$ ). The 200 and $3000 \mathrm{~m}$ isobaths delineate the region of the continental slope

\section{Fishery and seabird assemblage}

The Uruguayan pelagic longline fleet targets swordfish, yellow-fin tuna, bigeye tuna, albacore, and pelagic sharks (mainly blue shark). Between 9 and 12 vessels $\mathrm{yr}^{-1}$, with lengths ranging from 15 to $37 \mathrm{~m}$, were active in the period 2005 to 2008. During this period, 20 commercial fishing trips were carried out on 10 different vessels, during which a total of 415 bird counts were performed (Table 1). We performed 3 counts $\mathrm{d}^{-1}$ (morning, around noon, and afternoon-evening) as described by Jiménez et al. (2009b), which were considered independent. Morning counts were initiated between 06:30 and 09:30 h, coinciding with the first hour of longline hauling. Midday counts took place between 10:30 and 13:30 h and mainly during hauling or at the end of hauling (navigating). Afternoon counts were initiated between 16:30 and 19:30 h during daylight hours, before or the early stages of gear setting. In some cases it was impossible to complete the 3 daily counts due to bad weather. From aft of the boat, an area encompassing about $200 \times 400 \mathrm{~m} \mathrm{(} \mathrm{200} \mathrm{m}$ from the stern and $\sim 200 \mathrm{~m}$ to port and to starboard) was observed during approximately $30 \mathrm{~min}$, during which the number of individuals of each species was counted and the behavior of the species was recorded (see below and next section). During seabird
Table 1. Number of seabird counts and number of days on which counts were performed while on board pelagic longline fishing vessels on the continental slope of Uruguay and adjacent waters (2005 to 2008)

\begin{tabular}{|lllcc|}
\hline Trip & Year & Month & $\begin{array}{c}\text { No. of } \\
\text { days }\end{array}$ & $\begin{array}{c}\text { No. of } \\
\text { Counts }\end{array}$ \\
\hline 1 & 2005 & February & 3 & 8 \\
2 & & May & 16 & 45 \\
3 & & July & 9 & 26 \\
4 & & October & 2 & 5 \\
5 & & November & 3 & 6 \\
6 & & December & 17 & 46 \\
7 & \multirow{2}{*}{2006} & March & 11 & 30 \\
8 & & May & 9 & 22 \\
9 & & June & 7 & 14 \\
10 & & October-November & 6 & 15 \\
11 & & December & 6 & 14 \\
12 & 2007 & Feb-March & 10 & 25 \\
13 & & April & 7 & 14 \\
14 & & July-August & 12 & 24 \\
15 & & December & 3 & 8 \\
16 & 2008 & March-April & 2 & 3 \\
17 & & May-June & 8 & 21 \\
18 & & May-June & 11 & 27 \\
19 & & August-September & 16 & 40 \\
20 & & October-November & 10 & 22 \\
Total & & & 168 & 415 \\
\hline
\end{tabular}

counts, it was usually necessary to resort to estimations rather than absolute counts. In these cases, we made some attempts to count the number of birds of each species from which we estimated the number of individuals in the sampled area. The activity of the vessel was recorded in 1 of 3 categories: hauling, navigating, and setting the longline. The vessels tend to work relatively far from each other for operational reasons (e.g. entanglements between lines). Occasionally we observed a single boat, so the number of ships fishing together was not considered an important factor influencing the abundance of seabirds in this fishery.

The structure of the assemblage was described in terms of species richness, abundance, and biomass. We calculated the maximum potential number of species composing the assemblage using re-sampling tools (Chao 1, Chao 2, Jackknife 1, Jackknife 2, and bootstrap) using the program EstimateS v8.2 (http://purl.oclc.org/estimates). To analyze the abundances of species, we used the relative frequency of occurrence $(\% \mathrm{FO}$, i.e. the number of counts in which a species occurred as a percent of total counts), the total number, the mean $( \pm \mathrm{SD})$, and the range of individuals observed across all counts performed in the study period, and across seasons (see below). Biomass was estimated as the number of individuals observed, multiplied by the average mass of the 
species (see the Supplement at www.int-res.com/ articles/suppl/n015p241_supp.pdf).

To analyze the composition and abundance of the species in different months of the year, we performed a correspondence analysis. For this analysis, each count $(n=415)$ was classified according to the month in which it took place (there were no data for January throughout the $4 \mathrm{yr}$ of the study; see Table 1). Based on this analysis, we defined 2 periods (October to April and May to September, see 'Results'). We carried out a sample-based rarefaction analysis (Gotelli \& Colwell 2001) in order to compare the richness of species between these 2 periods, using EstimateS v 8.2. In order to determine if there were significant differences between the abundances of each species between the 2 periods, we used a Mann-Whitney test.

The effects of the activity of the boat and season on bird abundances were evaluated and modeled using a generalized linear model (GLM). The time of day at which the count took place (i.e. morning, midday, or afternoon) was not used in this analysis, as it was correlated to the activity of the vessel. The dependent variable was 'bird abundance' (count variable), and the independent variables incorporated as categorical variables were 'vessel activity' and 'season'. 'Vessel activity' comprised 3 categories: hauling, navigating, and setting, and 'season' had 2 categories: October to April and May to September (see 'Results'). We used a Poisson distribution for count data for the response variable with a 'log' link function. This analysis was developed in the software R v 2.6.1 (www.r-project.org/). After this analysis, we independently evaluated the effect of the variable 'vessel activity' on bird abundance using paired comparisons (Mann-Whitney test).

\section{Behavioral characterization}

We considered 'discards' to be the species captured (including several pelagic fishes) and discarded (whole or in parts), the viscera, and pieces of fish resulting from onboard processing and the used bait (squid and mackerel) discarded into the sea. Discards were released into the ocean during the longline hauling. During 172 of 415 counts during hauling, we recorded the behavior of the species in the following 5 categories: (1) swimming (or resting on the water); (2) diving; (3) flying; (4) feeding (when a bird was observed consuming discards); (5) competing for discards. Competitive interactions were defined as situations in which 1 individual displaced one or more others which were trying to feed on discards, by intimidation or by contact during an aggressive encounter. We recorded whether the interaction was intra- or interspecific, and in the latter case, we recorded the identity of the dominant species (i.e. which species ultimately consumed the discards, or part of the discards) and which was the subordinate species. During the counting period (see previous section), for each species we used scan sampling to record whether behaviors were observed or not (i.e. 0/1 sampling; Dawkins 2007). This method was chosen because it does not require recording the absolute number or proportion of individuals performing each behavior, which greatly simplifies the recording process. For the behavior of interspecific competition, we took as many records for each dominant species as subordinate species displaced.

We estimated the relative frequency of each behavior per species (i.e. the percent of samples in which the behavior was observed out of the total number of samples in which that species was present). To characterize the assemblage based on behavior, and to determine the species that make use of the discards, we performed a correspondence analysis with the frequency data mentioned above. We constructed $2 \times 2$ contingency tables for the principal species observed foraging on discards. We used as categories the 2 identified periods of the year and as classification criteria the number of samples in which each behavior was observed or not. We used a $\chi^{2}$ test to evaluate whether there were seasonal differences in foraging frequency, interspecific competition, and intraspecific competition.

We analyzed interspecific competition based on our direct observations of the frequency of species displacements (see Table 4), following Wallace \& Temple (1987). This analysis was carried out for the species that showed an association with discards during longline hauling, and included data from 184 direct observations of aggressive encounters. We evaluated the correlation between the obtained hierarchical order and body mass of each species using a Spearman correlation.

\section{RESULTS}

\section{Seabird assemblage}

During the study period, we recorded a total of 34979 seabirds, equivalent to a biomass of $59795 \mathrm{~kg}$, in association with the longline fishery. The assemblage included at least 38 species (Table 2). The 
Table 2. Abundance (total number [n], mean, minimum, and maximum number of individuals), relative frequency of occurrence (\%FO), and biomass (kg) of seabirds associated with pelagic longline fishing ( $\mathrm{n}=415$ counts) during 2005 to 2008 . \% of total biomass: \% of all seabird biomass estimated for study area and period. Status is shown by IUCN criteria, where CR: Critically Endangered, EN: Endangered, VU: Vulnerable, NT: Near Threatened, LC: Least Concern (see details in www.birdlife.org/datazone/species/search)

\begin{tabular}{|c|c|c|c|c|c|c|c|c|c|c|c|}
\hline Species & & $\begin{array}{l}\text { Species } \\
\text { code }\end{array}$ & Status & $\mathrm{n}$ & Mean & $\mathrm{SD}$ & Min. & Max. & $\% \mathrm{FO}$ & Biomass & $\begin{array}{c}\% \text { of } \\
\text { total } \\
\text { biomass }\end{array}$ \\
\hline $\begin{array}{l}\text { Wandering and Tristan } \\
\text { albatrosses }\end{array}$ & $\begin{array}{l}\text { Diomedea exulans }{ }^{\mathrm{a}} \text { and } \\
\text { D. dabbenena }\end{array}$ & DEX & VU/CR & 376 & 0.91 & 1.76 & 0 & 16 & 36.4 & 2733.5 & 4.6 \\
\hline Southern royal albatross & Diomedea epomophora & DEP & VU & 82 & 0.2 & 0.66 & 0 & 6 & 11.3 & 623.2 & 1.0 \\
\hline Northern royal albatross & Diomedea sanfordi & DSA & EN & 174 & 0.42 & 0.89 & 0 & 5 & 24.1 & 1160.6 & 1.9 \\
\hline White-capped albatross & Thalassarche steadi & TST & NT & 187 & 0.45 & 1.68 & 0 & 20 & 19 & 691.9 & 1.2 \\
\hline Black-browed albatross & Thalassarche melanophrys & TME & EN & 7370 & 17.76 & 28.9 & 0 & 150 & 71.6 & 23362.9 & 39.1 \\
\hline $\begin{array}{l}\text { Atlantic yellow-nosed } \\
\text { albatross }\end{array}$ & $\begin{array}{l}\text { Thalassarche } \\
\text { chlororhynchos }\end{array}$ & $\mathrm{TCH}$ & EN & 1685 & 4.06 & 7.81 & 0 & 70 & 58.6 & 3707.0 & 6.2 \\
\hline Sooty albatross & Phoebetria fusca & PHF & EN & 8 & 0.02 & 0.15 & 0 & 2 & 1.69 & 20.0 & 0.0 \\
\hline $\begin{array}{l}\text { Northern and southern } \\
\text { giant petrels }\end{array}$ & $\begin{array}{l}\text { Macronectes halli and } \\
\text { M. giganteus }\end{array}$ & MAC & LC/LC & 1661 & 4 & 9.7 & 0 & 73 & 46.8 & 6311.8 & 10.6 \\
\hline White-chinned petrel & Procellaria aequinoctialis & PAQ & VU & 5310 & 12.8 & 22.1 & 0 & 150 & 69.2 & 6956.1 & 11.6 \\
\hline Spectacled petrel & Procellaria conspicillata & $\mathrm{PCO}$ & VU & 7158 & 17.25 & 32.4 & 0 & 200 & 66.8 & 8518.0 & 14.3 \\
\hline Grey petrel & Procellaria cinerea & PCI & NT & 3 & 0.01 & 0.08 & 0 & 1 & 0.72 & 3.4 & 0.0 \\
\hline Cape petrel & Daption capensis & DCA & $\mathrm{LC}$ & 3222 & 7.76 & 15 & 0 & 100 & 50.6 & 1449.9 & 2.4 \\
\hline Southern fulmar & Fulmarus glacialoides & FGL & LC & 332 & 0.8 & 2.8 & 0 & 30 & 21.2 & 262.3 & 0.4 \\
\hline Gadfly petrel $^{\mathrm{b}}$ & Pterodroma sp. & PTE & & 1 & 0 & 0.05 & 0 & 1 & 0.24 & 0.0 & 0.0 \\
\hline Atlantic petrel & Pterodroma incerta & PIN & EN & 723 & 1.74 & 4.84 & 0 & 60 & 51.3 & 390.4 & 0.7 \\
\hline Soft-plumaged petrel & Pterodroma mollis & PMO & $\mathrm{LC}$ & 41 & 0.1 & 0.83 & 0 & 15 & 4.34 & 11.5 & 0.0 \\
\hline Trindade petrel & Pterodroma arminjoniana & PAR & VU & 1 & 0 & 0.05 & 0 & 1 & 0.24 & 0.4 & 0.0 \\
\hline $\begin{array}{l}\text { Cory's and Cape Verde } \\
\text { shearwaters }\end{array}$ & $\begin{array}{l}\text { Calonectris diomedea and } \\
\text { C. edwardssi }\end{array}$ & CAL & $\mathrm{LC} / \mathrm{NT}$ & 4 & 0.01 & 0.1 & 0 & 1 & 0.96 & 0.0 & 0.0 \\
\hline Cory's shearwater & C. diomedea & CDI & $\mathrm{LC}$ & 66 & 0.16 & 0.5 & 0 & 4 & 12.1 & 35.6 & 0.1 \\
\hline Cape Verde shearwater & C.edwardsii & CED & NT & 6 & 0.01 & 0.14 & 0 & 2 & 1.2 & 2.9 & 0.0 \\
\hline Shearwater ${ }^{b}$ & Puffinus sp. & PUF & & 8 & 0.02 & 0.35 & 0 & 7 & 0.48 & 0.0 & 0.0 \\
\hline Great shearwater & Puffinus gravis & PUG & $\mathrm{LC}$ & 3422 & 8.25 & 18.8 & 0 & 200 & 66.3 & 3011.4 & 5.0 \\
\hline Sooty shearwater & Puffinus griseus & PGR & NT & 552 & 1.33 & 8.53 & 0 & 80 & 10.8 & 386.4 & 0.6 \\
\hline Manx shearwater & Puffinus puffinus & PPU & $\mathrm{LC}$ & 29 & 0.07 & 0.36 & 0 & 5 & 5.3 & 12.8 & 0.0 \\
\hline Prions & Pachytila spp. & PAC & & 46 & 0.11 & 0.65 & 0 & 9 & 6.27 & 0.0 & 0.0 \\
\hline Antarctic prion & Pachyptila desolata & PDE & $\mathrm{LC}$ & 35 & 0.08 & 0.62 & 0 & 9 & 4.1 & 5.6 & 0.0 \\
\hline Wilson's storm petrel & Oceanites oceanicus & OOC & $\mathrm{LC}$ & 2289 & 5.52 & 10.4 & 0 & 60 & 62.7 & 68.7 & 0.1 \\
\hline $\begin{array}{l}\text { Black- and white-bellied } \\
\text { storm petrels }\end{array}$ & $\begin{array}{l}\text { Fregetta tropica and } \\
\text { F. grallaria }\end{array}$ & FRE & LC/LC & 5 & 0.01 & 0.16 & 0 & 3 & 0.72 & 0.0 & 0.0 \\
\hline Black-bellied storm petrel & Fregetta tropica & FTR & $\mathrm{LC}$ & 17 & 0.04 & 0.23 & 0 & 2 & 3.37 & 1.0 & 0.0 \\
\hline Skuas & Catharacta spp. & $\mathrm{CHA}$ & & 28 & 0.07 & 0.3 & 0 & 3 & 5.54 & 0.0 & 0.0 \\
\hline Pomarine jaeger & Stercorarius pomarinus & SPO & $\mathrm{LC}$ & 60 & 0.14 & 0.65 & 0 & 5 & 6.51 & 44.4 & 0.1 \\
\hline $\begin{array}{l}\text { Parasitic and long-tailed } \\
\text { jaegers }\end{array}$ & $\begin{array}{l}\text { Stercorarius parasiticus }{ }^{\mathrm{a}} \\
\text { and } S . \text { longicaudus }\end{array}$ & SPL & LC/LC & 43 & 0.1 & 0.77 & 0 & 14 & 5.06 & 20.6 & 0.0 \\
\hline Gull $^{\mathrm{b}}$ & Lariidae sp. & LAR & & 6 & 0.01 & 0.14 & 0 & 2 & 1.2 & 0.0 & 0.0 \\
\hline Brown-hooded gull & Larus maculipennis & LMA & $\mathrm{LC}$ & 1 & 0 & 0.05 & 0 & 1 & 0.24 & 0.3 & 0.0 \\
\hline Tern $^{b}$ & Sterna sp. & STE & & 23 & 0.06 & 0.31 & 0 & 3 & 3.61 & 0.0 & 0.0 \\
\hline South American tern & Sterna hirundinacea & $\mathrm{STH}$ & $\mathrm{LC}$ & 4 & 0.01 & 0.1 & 0 & 1 & 0.96 & 0.8 & 0.0 \\
\hline Masked booby & Sula dactylatra & $\mathrm{SDA}$ & $\mathrm{LC}$ & 1 & 0 & 0.05 & 0 & 1 & 0.24 & 1.6 & 0.0 \\
\hline
\end{tabular}


results of the richness estimators indicated that the potential number of species making up the assemblage was between 39 and 44 (Chao $1=43.0 \pm 7.3$; Chao $2=40.0 \pm 4.2$; Jackknife $1=41.0 \pm 2.0$; Jackknife $2=44.0$ species; bootstrap $=38.8$ species $)$. In terms of abundance, \% $\mathrm{FO}$, and biomass, the most important species of the assemblage was blackbrowed albatross, followed by spectacled petrel and white-chinned petrel. Other species that were important in terms of abundance and frequency were great shearwater Puffinus gravis, cape petrel Daption capense, Wilson's storm petrel Oceanites oceanicus, Atlantic yellow-nosed albatross, giant petrels (Macronectes halli and M. giganteus pooled), and Atlantic petrel. The most important species in terms of biomass were giant petrels, Atlantic yellow-nosed albatross, great shearwater, and wandering albatross sensu lato (wandering and Tristan albatrosses pooled; Table 2).

The results of the correspondence analysis of temporal variation in the assemblage are shown in Fig. 2. Axis 1 explains $56.8 \%$ of the inertia and separated the months between austral spring and the beginning of austral autumn (October to April) from the months between mid-autumn and winter (May to September). This separation was associated on 1 side with a group of species that reproduce in the archipelagos of Tristan de Cunha and Gough (in the central South Atlantic) or north of the study area (e.g. Trindade and islands of the North Atlantic) and on the other side by a group of species that breed to the south of the study area (i.e. the Falklands/Malvinas, South Georgia, and other sub-Antarctic islands and the Antarctic). The separation of the second axis was given principally by the months of May and June, and the rest of the months. The main species supporting this separation were great shearwater and sooty shearwater Puffinus griseus associated with their aggregation in the study area prior to their transequator migration.

Based on the correspondence analysis, we considered 2 periods (October to April and May to September) for the analysis of seasonal variation in richness and abundance of seabirds. The rarefaction curves show that the assemblage had greatest richness during the period October to April (Fig. 3). We recorded statistically significant differences in the abundance of birds for 14 species during both seasons (see Table S2 in the supplement at www.int-res.com/articles/suppl/n015p241_ supp.pdf). During the period October to April, the species that increased compared to May to Sep-

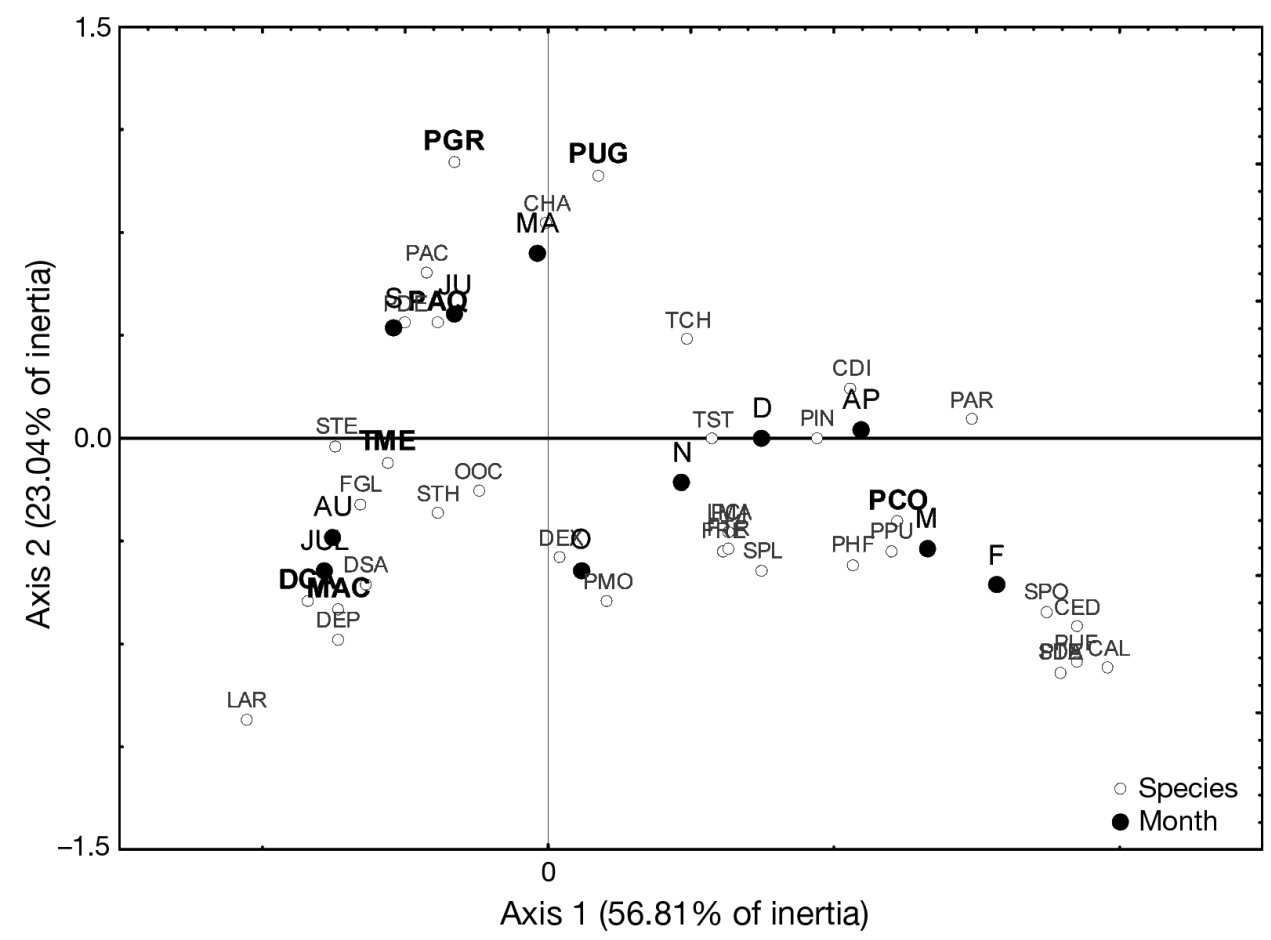

Fig. 2. Correspondence analysis of the temporal variation in abundance and richness of seabirds associated with the pelagic longline fishery on the continental slope of Uruguay and adjacent waters (2005 to 2008). (O): months (F: February, M: March, Ap: April, MA: May, JU: June, JUL: July, AU: August, S: September, O: October, N: November, D: December) (O): species. Species in bold and larger font explained more than $5 \%$ of the variance, at least for 1 axis. Species codes as in Table 2 


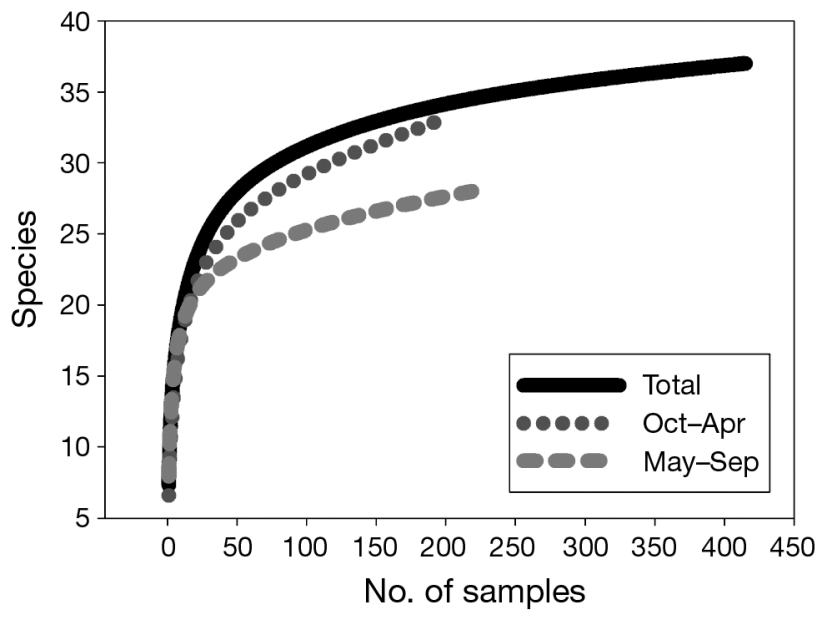

Fig. 3. Sample-based rarefaction curves for the assemblage of seabirds associated with the pelagic longline fishery on the Uruguayan continental slope and adjacent waters (2005 to 2008). The curve is for the total study period ( $\mathrm{n}=415$ counts), and for the periods October to April $(\mathrm{n}=196)$ and May to September $(n=219)$

tember were, in order of importance: spectacled petrel, Atlantic yellow-nosed albatross, Atlantic petrel, and pomarine jaeger Stercorarius pomarinus. By contrast, 10 species (i.e. black-browed albatross, white-chinned petrel, cape petrel, Wilson's storm petrel, giant petrel, sooty shearwater, southern fulmar Fulmarus glacialoides, northern royal albatross Diomedea sanfordi, southern royal albatross D. epomophora, and prions Pachyptila spp.) were more abundant in May to September (see Table S2). Various species did not show significant differences in abundance between the analyzed seasons. These included rare and infrequent species (i.e. with very low \%FO, see Table 2) or species whose variations in abundance across the year did not coincide with our defined seasons (e.g. great shearwater and wandering albatross sensu lato).

The mean abundance of seabirds per count during the study period was $91.3 \pm 70.2$ birds (median: 70 ; range: $1-385$ ). The results of the GLM indicated that the 2 variables that we evaluated (i.e. season and vessel activity) and their interaction significantly ( $\mathrm{p}<$ 0.01 ) influenced the abundance of seabirds (Table 3). Vessel activity explained the greatest proportion of the model deviance (i.e. $78.0 \%$ ), followed by season $(20.2 \%)$ and their interaction $(1.8 \%)$. The comparisons showed that variations in bird abundances related to vessel activity were due to differences between counts made during hauling (Fig. 4). The greatest abundance of seabirds occurred in the period May to September (Fig. 5).
Table 3. Deviance analysis of explanatory variables for the abundance of seabirds (number of individuals) of the generalized linear model. The $p$-value refers to the $\chi^{2}$ test

\begin{tabular}{|lccccc|}
\hline & df & $\begin{array}{c}\text { Residual } \\
\text { deviance }\end{array}$ & $\begin{array}{c}\text { Change in } \\
\text { deviance }\end{array}$ & p & $\begin{array}{c}\text { \% of explained } \\
\text { deviance }\end{array}$ \\
\hline Null & & 20761 & & & \\
Activity & 2 & 13730 & 7032 & $<0.01$ & 78.0 \\
Season & 1 & 11907 & 1823 & $<0.01$ & 20.2 \\
Activity $\times$ & 2 & 11744 & 163 & $<0.01$ & 1.8 \\
$\quad$ Season & & & & & \\
\hline
\end{tabular}

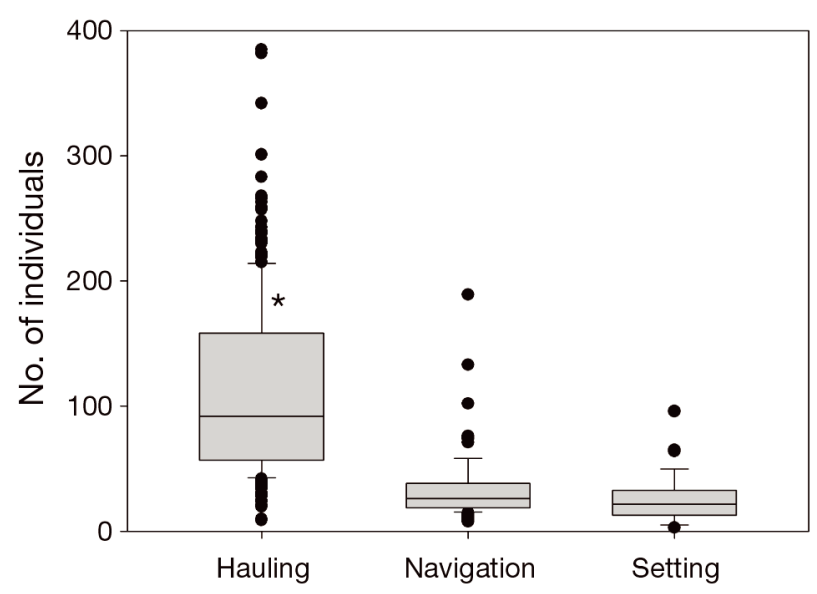

Fig. 4. Variation in the abundance of seabirds associated with pelagic longline fisheries sorted by vessel activity (2005 to 2008). Hauling, $\mathrm{n}=310$, navigating, $\mathrm{n}=66$, and setting, $\mathrm{n}=39$ counts, respectively. The line in the box shows the median; bottom and top of the box show the 25th and 75th percentile, respectively; whisker caps represent the $95 \%$ confidence interval; and dots show the outliers. Paired Mann-Whitney comparisons: * $\mathrm{p}<0.05$

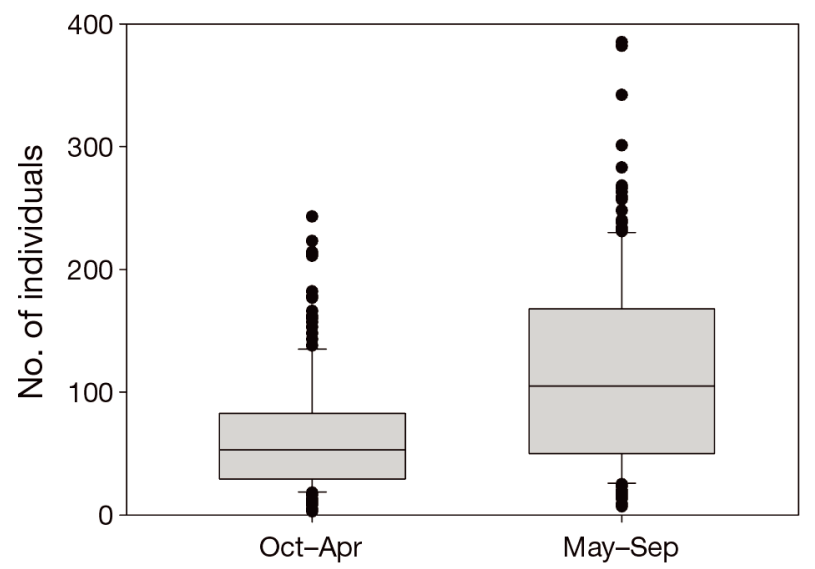

Fig. 5. Seasonal variation in the abundance of seabirds associated with the pelagic longline fishery (2005 to 2008; October to April, $n=196$ counts; May to September, $n=219$ counts). Layout of box plots as in Fig. 4 


\section{Use of discards and interactions}

The correspondence analysis permitted us to identify the species that make use of discards, primarily including competitively dominant species and species that obtained discards by diving (Fig. 6). Axis 1 explains $61.0 \%$ of the inertia and separates the behavior 'flying' from the rest of the categories, with 'feeding' being the most important $(16.5 \%$ of the inertia). This separation was strongly associated on one side with the species with a low affinity for discards (e.g. Calonectris spp., Pachyptila spp., Fregetta spp., Larus spp., Sterna spp.) and on the other side by the albatrosses and petrels that exploited discards. Axis 2 separated 'diving' from 'interspecific competition.' This separation was strongly associated with shearwaters and medium-sized petrels on the one side and by albatrosses on the other.

A total of 18 taxa fed on discards. Some did so infrequently, including Wilson's storm petrel (possibly underestimated due to the difficulty of observation) and Atlantic petrel $(2.1 \%, \mathrm{n}=97$ and $5.5 \%, \mathrm{n}=109$; respectively). A further 4 taxa occurred infrequently near boats (i.e. Stercorarius spp., pomarine jaeger, Catharacta spp., and Larus spp., see Table 2). A more detailed analysis of the 12 main taxa (14 species) that fed on discards in each period is shown in Fig. 7. Five species showed significant differences between periods in frequency of feeding behavior (Fig. 7a). Intraspecific competition was rare or absent in the large albatrosses, but was observed in the other species in at least 1 season (Fig. 7b). The species that displayed intraspecific competition with greater frequency in October to April were spectacled petrel, whitechinned petrel, and Atlantic yellow-nosed albatross, with giant petrel and great shearwater showing the opposite pattern (Fig. 7b). In black-browed albatross, the frequency of intraspecific competition tended to be greater in May to September, although not significantly. The remaining species displaying intraspecific competition did so with low frequency $(<15 \%)$ and in only 1 season (Fig. 7b). Success in interspecific competitive interactions, defined as displacing the other species, was more frequent in albatross species (Fig. 7c). In these species we observed significant differences in frequency of interspecific competition only for white-capped albatross and Atlantic yellownosed albatross, for which competition was higher in October to April. The opposite, though non-significant, tendency was observed between periods for

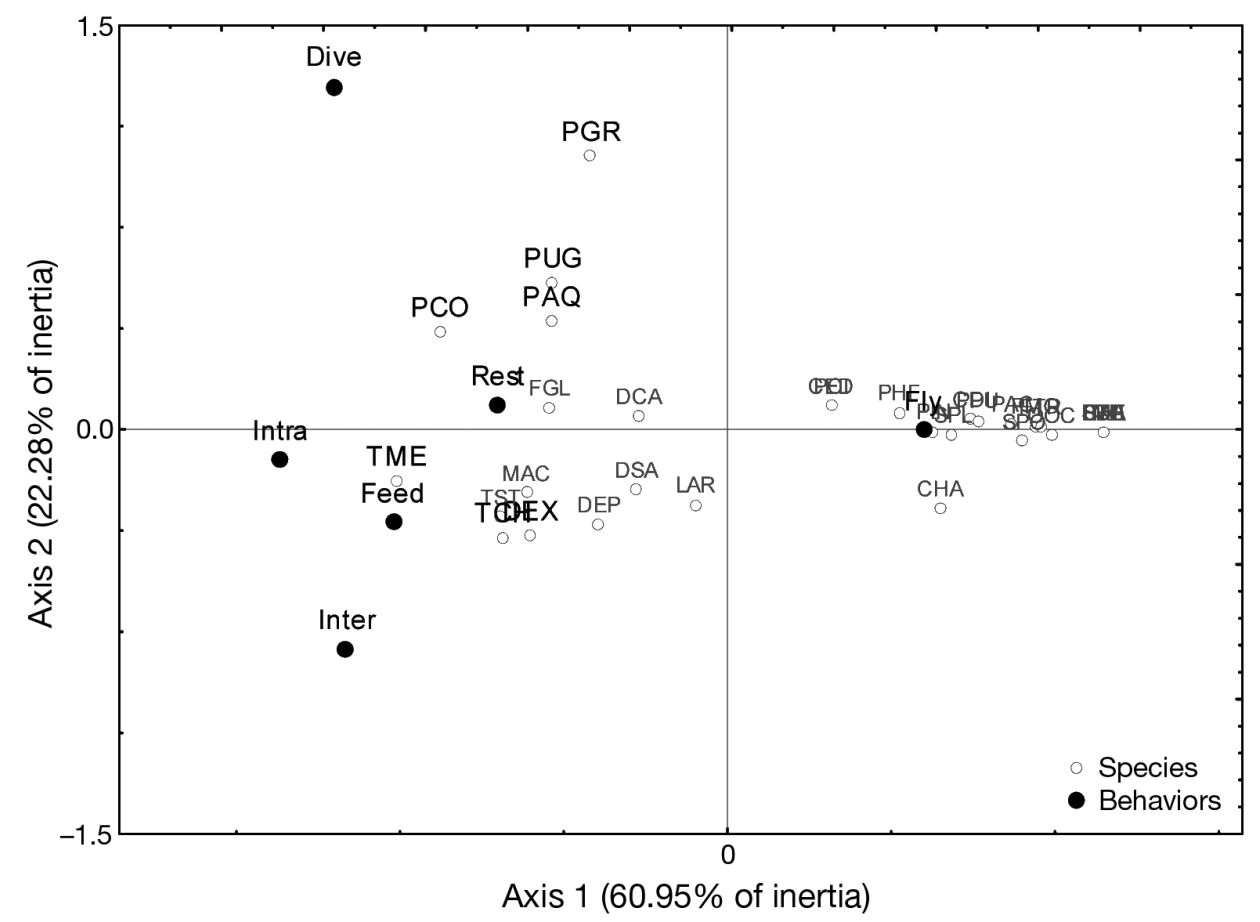

Fig. 6. Correspondence analysis of seabird behavior associated with the pelagic longline fishery (2005 to 2008). (•): behaviors observed during counts that took place during longline hauling $(\mathrm{n}=172$; Intra: intraspecific competition, Inter: interspecific competition); (O): species. Species in bold and larger font explained more than $5 \%$ of the variance, at least for 1 axis. Species adjacent to 'Fly' in the graph are PHF, PCI, PTE, PIN, PMO, CAL, CDI, CED, PUF, PPU, PAC, PDE, OOC, FRE, FTR, CHA, SPL, SPO, LMA, STE and STH. Species codes as in Table 2 

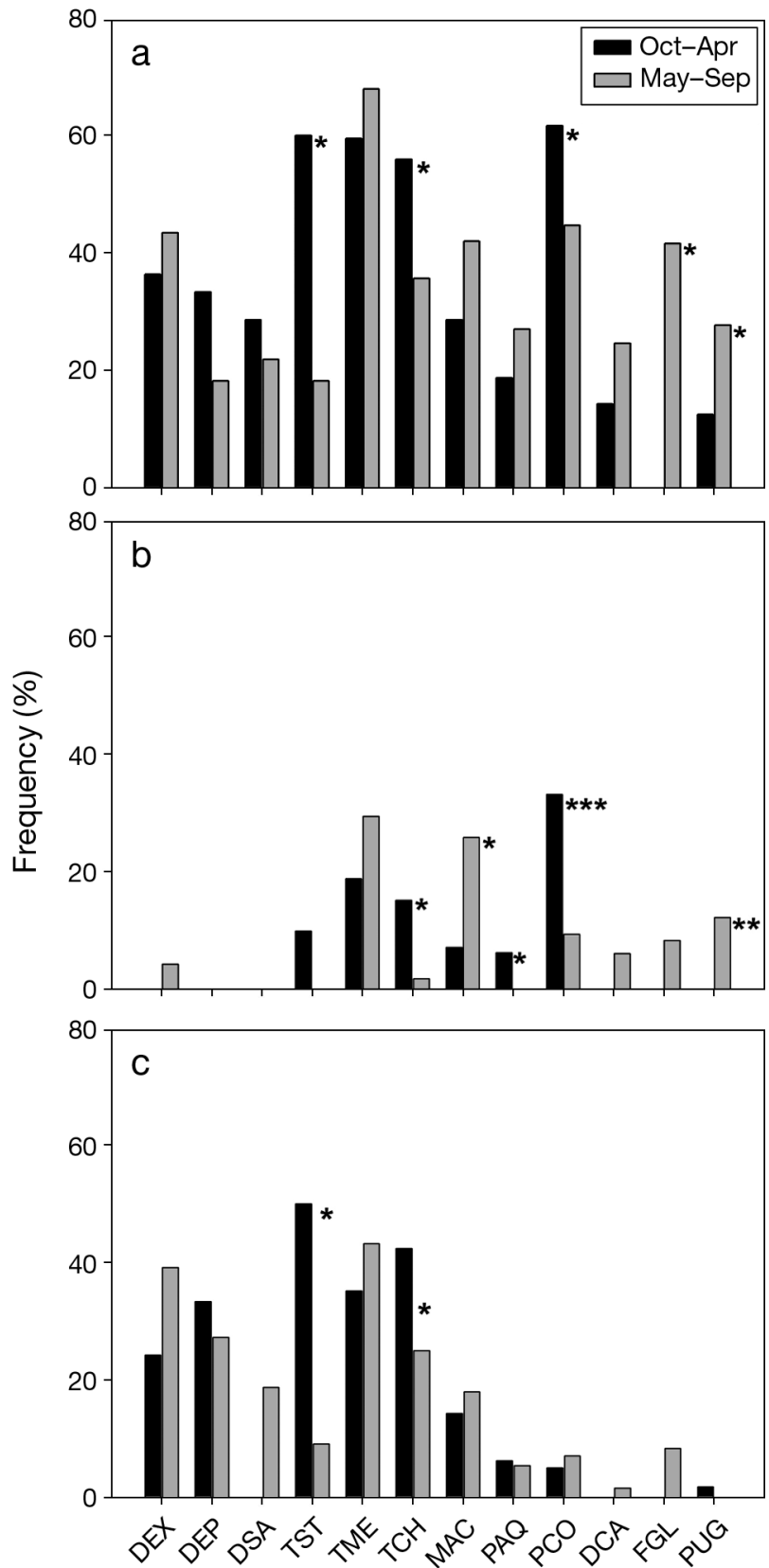

Fig. 7. Relative frequency of behaviors (i.e. number of samples in which the behavior was observed as a percent of the total number of counts in which the species was observed), specifically (a) feeding, (b) intraspecific competition, and (c) interspecific competition, in the main species that exploited discards, viscera, and bait during longline hauling (2005 to 2008) during the periods October to April ( $\mathrm{n}=61$ counts) and May to September ( $\mathrm{n}=111$ counts). Species codes as in Table 2. $\chi^{2}$ test: ${ }^{*} \mathrm{p}<0.05,{ }^{* *} \mathrm{p}<0.01$, ${ }^{* * *} \mathrm{p}<0.001$

wandering albatross sensu lato, northern royal albatross, black-browed albatross, and giant petrel (Fig. 7c). The relative frequency of interspecific competition was low in the remaining petrels (Fig. 7c).
During the hauling of the longline, we recorded 184 interspecific interactions between the principal taxa that fed on discards, from which we determined the competitive hierarchy (Table 4). The first ranks in the hierarchy were most difficult to determine due to the low number of interactions observed between these species (mainly Diomedea spp.). Wandering albatross sensu lato competed successfully with 9 of the 12 taxa with which they interacted for access to discards, losing only 1 interaction with northern royal albatross. Consequently, it was placed at the top of the competitive hierarchy. Based on the outcome of a single interspecific interaction, southern and northern royal albatrosses were placed in the second and third positions, respectively. In fourth and fifth position we placed white-capped albatross and giant petrel, respectively, which successfully displaced various species. We did not observe interactions between these 2 taxa; however, giant petrels were always displaced by large albatrosses. For the other species, the ranking was clearer (Table 4). The hierarchical order based on these results was negatively correlated with body mass (Spearman $\mathrm{R}=-0.99$, $\mathrm{p}<$ 0.01).

\section{DISCUSSION}

\section{Seabird assemblage}

The southwest Atlantic has been identified as one of the most important regions of the planet in terms of richness, abundance, and biomass of procellariiforms (Veit 1995, Croxall \& Wood 2002, Favero \& SilvaRodríguez 2005). This is principally due to the presence of the Falkland/Malvinas Islands and South Georgia, the proximity of Tristan da Cunha and Gough Island, archipelagos of global importance for the reproduction of albatrosses and petrels, and the presence of species arriving from remote areas (e.g. New Zealand and the North Atlantic). The richness of seabird species observed in association with pelagic longliners within the study area (i.e. > 38 species) is greater than that observed in any other longline or trawl fishery (i.e. a range of 12 to 23 species) operating in the southwest Atlantic (Vaske 1991, Olmos 1997, Yorio \& Caille 1999, González-Zevallos \& Yorio 2006, Olmos \& Bugoni 2006, Sullivan et al. 2006, Gandini \& Seco Pon 2007, González-Zevallos et al. 2007, Bugoni et al. 2008, Favero et al. 2011, Goetz et al. 2011). This may be explained by the presence of the $\mathrm{BMC}$, the dynamic of which (see next section) determines that the assemblage under study is tran- 
Table 4. Results of the observations of interspecific competition $(n=184)$ made during longline hauling and the proposed hierarchical rankings. The percent of interactions in which species A successfully competed for discards with species B are indicated (see 'Materials and methods' for definitions), with the number of interactions in parentheses. Species codes as in Table 2. Data sources are shown in Supplement 1

\begin{tabular}{|c|c|c|c|c|c|c|c|c|c|c|c|c|c|c|}
\hline $\begin{array}{l}\text { Species } \\
\text { A }\end{array}$ & DEX & DEP & DSA & TST & TME & $\overline{\mathrm{TCH}}$ & $\begin{array}{c}\text { Species B } \\
\text { MAC }\end{array}$ & PAQ & $\mathrm{PCO}$ & $\mathrm{DCA}$ & FGL & PUG & $\begin{array}{l}\text { Hierarchy } \\
\text { rank }\end{array}$ & $\begin{array}{c}\text { Body } \\
\text { mass }(k g)\end{array}$ \\
\hline DEX & - & $100(1)$ & $0(1)$ & 0 & $100(5)$ & $100(2)$ & $100(11)$ & $100(5)$ & $100(4)$ & $100(1)$ & $100(1)$ & $100(2)$ & 1 & 7.27 \\
\hline DEP & $0(1)$ & - & $100(1)$ & 0 & $100(2)$ & 0 & $100(2)$ & 0 & 0 & 0 & 0 & 0 & 2 & 7.6 \\
\hline DSA & $100(1)$ & $0(1)$ & - & 0 & $100(4)$ & 0 & $100(3)$ & 0 & 0 & $100(1)$ & 0 & 0 & 3 & 6.67 \\
\hline TST & 0 & 0 & 0 & - & $100(5)$ & $100(1)$ & 0 & $100(2)$ & $100(7)$ & 0 & 0 & 0 & 4 & 4.35 \\
\hline TME & $0(5)$ & $0(2)$ & $0(4)$ & $0(5)$ & - & $83(6)$ & $0(8)$ & $100(10)$ & $100(13)$ & $100(7)$ & $100(11)$ & $100(8)$ & 6 & 3.17 \\
\hline $\mathrm{TCH}$ & $0(2)$ & 0 & 0 & $0(1)$ & $17(6)$ & - & 0 & $100(1)$ & $96(26)$ & $100(1)$ & 0 & $100(8)$ & 7 & 2.2 \\
\hline MAC & $0(11)$ & $0(2)$ & $0(3)$ & 0 & $100(8)$ & 0 & - & 100 (1) & $100(1)$ & $100(2)$ & 0 & $100(1)$ & 5 & 3.8 \\
\hline PAQ & $0(5)$ & 0 & 0 & $0(2)$ & $0(10)$ & $0(1)$ & $0(1)$ & - & $60(5)$ & $100(1)$ & $100(1)$ & $100(2)$ & 8 & 1.31 \\
\hline $\mathrm{PCO}$ & $0(4)$ & 0 & 0 & $0(7)$ & $0(13)$ & $4(26)$ & $0(1)$ & $40(5)$ & - & 0 & $100(1)$ & $80(5)$ & 9 & 1.19 \\
\hline DCA & $0(1)$ & 0 & $0(1)$ & 0 & $0(7)$ & $0(1)$ & $0(2)$ & $0(1)$ & 0 & - & $25(4)$ & 0 & 12 & 0.45 \\
\hline FGL & 0 (1) & 0 & 0 & 0 & $0(11)$ & 0 & 0 & 0 (1) & $0(1)$ & $75(4)$ & - & 0 & 11 & 0.79 \\
\hline PUG & $0(2)$ & 0 & 0 & 0 & $0(8)$ & $0(8)$ & $0(1)$ & $0(2)$ & $20(5)$ & 0 & 0 & - & 10 & 0.88 \\
\hline
\end{tabular}

sitional, including in the same area species typical of the Brazilian Current as well as of the cold Malvinas Current (Veit 1995, Olmos 2002, Neves et al. 2006, Bugoni et al. 2009, Jiménez et al. 2009b), in different periods of the year. The continental slope is also likely to increase productivity and the availability of prey species (Veit 1995, see also Acha et al. 2004).

\section{Temporal variation}

Although the richness and abundance of seabird species associated with longline fisheries in Uruguay were previously studied in 2005 (Jiménez et al. 2009b), here we report the greatest observational effort to date (i.e. $4 \mathrm{yr}$ ), allowing us to determine the existence of substantial seasonal variance in species composition. The results of the correspondence analysis clearly show the occurrence of 2 different assemblages (Fig. 2), with the presence of the BMC playing an important role in their temporal separation. The seasons characterized by this study, viz. May to September and October to April, largely coincide with the periods when different masses of water predominate in the study area. The first period coincides in general terms with the predominance of sub-Antarctic waters, and the second with the presence of subtropical and tropical waters (Garcia 1998, Ortega \& Martínez 2007).

The species assemblage in May to September corresponds to the group of species that breed to the south of the study area (i.e. the Falklands/Malvinas, South Georgia, and other sub-Antarctic islands and the Antarctic), as shown by correspondence analysis. Similarly, the species typical of October to April are principally those that reproduce in the archipelagos of Tristan de Cunha and Gough (in the central South Atlantic) or north of the study area (e.g. Trindade and islands of the North Atlantic). The breeding phenology of the different species is thus an important factor in the interpretation of the 2 identified seasons. The breeding period of several species that reproduce annually in the Southern Hemisphere begins between September and November and ends between March and April (end of fledgling care). These periods are reversed in the breeding phenology of Northern Hemisphere seabirds (Harrison 1985, Onley \& Scofield 2007). At the end of the breeding season, the species that breed in the Falkland/Malvinas Islands, South Georgia, and other regions in the South Atlantic come to feed at the Uruguayan continental slope and adjacent waters. These species include, in order of abundance, black-browed albatross, whitechinned petrel, cape petrel, giant petrel, southern fulmar, northern royal albatross, and southern royal albatross, and it is these which account for the greater total abundance of birds during the period May to September. During this period, species that breed on Tristan da Cunha and Gough Island are observed principally towards the north of the BMC, associated with the Brazilian current (e.g. Atlantic yellow-nosed albatross and spectacled petrel; Bugoni et al. 2009, Jiménez et al. 2010). When the reproductive period in the Southern Hemisphere begins, individuals of the species that reproduce in the Falklands/Malivas, South Georgia, and other regions in the south progressively abandon the BMC. Then, as the Brazilian current begins to dominate the Uruguayan continental slope, species associated with this current, arrive in the study area, the most abundant of these during 
the summer months being the spectacled petrel. However, other species are also important, such as Atlantic petrel, which reproduces in Gough Island during June to December (Cuthbert 2004). Although their contribution to overall abundance in summer is small, Northern Hemisphere species characterize the summer assemblage (Olmos 2002).

Some exceptions to the observed temporal pattern can be explained by individual species' life histories, such as the trans-equator migration of great and sooty shearwaters (Onley \& Scofield 2007). This is evident in Axis 2 of the correspondence analysis (Fig. 2), reflecting the greater abundance of these species prior to migration. Other exceptions were the wandering albatross, which has a biennial breeding cycle. Incidental captures in this fishery allowed us to determine that these birds, primarily females, come from South Georgia and that their abundance increases between July and November at the end of the chick-rearing period (Jiménez et al. 2008, unpubl. data). This period coincides with observations for wandering albatross sensu lato during the present study. The Tristan albatross of Gough Island also occurs in this assemblage, as confirmed by incidental captures (authors' unpubl. data).

\section{Use of discards and interactions}

Variation in abundances of seabirds correlated to variation in abundance of discards has been shown in other fisheries (e.g. Weimerskirch et al. 2000, González-Zevallos \& Yorio 2006, Abraham et al. 2009). The greatest abundance of seabirds was observed during the longline hauling in the present study (see Fig. 4), due to the discards and waste generated during this activity (see 'Materials and methods'). As resources in the ocean are patchy, seabirds benefit from foraging in multi-species groups (Hoffman et al. 1981, Harrison et al. 1991). This is similar to what happens when fishing boats discard bycatch and waste. Some birds locate the boat during the beginning of the hauling, and their aggregation acts as a signal for the presence of food for other species of birds which join them. Some birds also benefit from the food sources made available by other species. For example, some petrels and shearwaters dive and bring bait and viscera to the surface where they are scavenged by other, often larger, species. Albatrosses and giant petrels with large beaks can also leave behind small pieces of large fish and viscera after feeding.

The correspondence analysis (Fig. 6) allowed us to characterize 2 species groups: species with little or no association with discards that usually fly through the sampled area, and species of albatross and petrel that make direct use of the resources made available by the fishery. These latter species interact inter- and intraspecifically, as observed in other longline fisheries (Vaske 1991, Olmos 1997). Other studies have described interspecific interactions during feeding on discards and bait in longline fisheries, suggesting a relationship between dominance and body size (Brothers 1991, Vaske 1991, Olmos 1997). We evaluated this hypothesis, confirming a strong negative correlation between hierarchical ranking and body mass, which indicates a higher probability of success in interspecific interactions as species' body mass increases.

Of the species that feed off this fishery, the petrels and shearwaters of medium size (e.g. white-chinned petrel, spectacled petrel, and great shearwater) forage by diving (see Fig. 6). In the majority of cases in which they forage successfully, they bring the food to the surface to consume it. Once on the surface, if the discard is not eaten rapidly, other birds compete for it. The intensity of intraspecific interactions for discards depends on the abundance of the species in question. Intraspecific competition occurred more frequently in the most abundant species in each season and was not observed in the less abundant species (i.e. southern and northern royal albatrosses). Medium-sized and small petrels compete intra- and interspecifically, with smaller individuals displaced by larger ones. Although albatrosses of the genus Thalassarche dive a few meters and also forage by surface seizing, they were also observed competing with and displacing small and medium-sized petrels and other Thalassarche spp. They were further observed to fly down when they saw a petrel diving, waiting to steal its food, and to steal food from birds manipulating or competing over food items. Giant petrels are usually more aggressive than Thalassarche albatrosses during aggressive encounters for food. These petrels form groups that interact very aggressively between species (Macronectes halli and M. giganteus) as well as intraspecifically. Finally, the large albatrosses displace the remaining species, generally descending to the surface of the ocean once they locate an established group of birds interacting in the vicinity of discards.

Although Atlantic petrels ingested discards only infrequently, when only individuals of this species were present, they displayed intraspecific competition for baits and small remains. This suggests that the competitive hierarchy displaces some smaller species that have an affinity for feeding off discards. 


\section{Implications for bycatch}

The 14 species that feed on discards in this fishery are frequently caught incidentally by longline fishing in the southwest Atlantic (Vaske 1991, Neves \& Olmos 1998, Bugoni et al. 2008, Jiménez et al. 2008, 2009a,b, 2010). Within the study area, sooty albatrosses Phoebetria fusca (Jiménez et al. 2010) and sooty shearwaters have been caught by the Uruguayan fleet. The former species was observed at very low frequency in this fishery, and we were unable to observe it feeding on discards. We observed sooty shearwaters diving for bait and viscera (see Fig. 6), although without success. However, outside the observation periods, these shearwaters were observed feeding off discards and attacking baits during hauling operations, and we recorded the incidental capture of some individuals which were released live (authors' unpubl. data).

The characterization of the temporal variation of the assemblage of seabirds associated with the pelagic longline fishery shows why there is a period of greater incidental capture of seabirds (i.e. May to November; Jiménez et al. 2009a) in this fishery. Species composition and abundance rather than species richness influence the rate of incidental capture. Of the taxa that feed on discards, 7 are more abundant in May to September and only 2 in October to April (see Table S2). Various species remain in the area during October and November, abandoning it progressively through to December. This is the case for black-browed albatross and white-chinned petrel, the 2 species most frequently bycaught in the area (Jiménez et al. 2009a, 2010). This might be because the majority of the black-browed albatross individuals (and possibly white-chinned petrel; see Bugoni \& Furness 2009) are immature. In the case of the wandering albatross, the greatest capture rate occurs in October and November (Jiménez et al. 2008). During most of the period of low capture rates, the principal species of the assemblage is the spectacled petrel. However, it is not clear why this species shows lower mortality rates due to longline fishing than its sister species, the white-chinned petrel (Bugoni et al. 2009, Jiménez et al. 2010).

Patterns of behavior observed during the longline hauling can also be useful for understanding how these species are captured during the setting of the longline. The competitive hierarchy related to body size establishes that larger species have greater access to discards and baits. This helps explain why albatrosses occupy the largest proportion of the incidental catch of seabirds in this fishery (Jiménez et al. 2009a, 2010). Petrels with high diving ability are more likely to access the bait. However, when they reach the surface with the bait, albatrosses can displace them easily and consume the bait (see previous section). This also occurs during longline setting (Jiménez et al. unpubl. data) as reported by Brothers (1991), who observed that grey petrels Procellaria cinerea brought bait up to the surface, which was then stolen by albatrosses. Across the Uruguayan continental slope and in adjacent waters, some petrels (mainly white-chinned and spectacled petrels) and great shearwaters are abundant. These species would increase the access to bait of at least 6 species of globally threatened albatross by bringing baits up to the surface from depths that albatrosses cannot reach.

It has been demonstrated that industrial fishery discards are of great importance to the viability of some threatened seabird species (e.g. Oro et al. 1996). Of the species that made significant use of discards in our study area, 8 species of albatross and petrel are globally threatened, including 1 listed as Critically Endangered and 3 as Endangered (Table 2). Considering the fishing effort (an indirect measure of discards) that the pelagic longline fleets expend over the region of the $\mathrm{BMC}$, the area of greatest concentration of effort in the southwestern Atlantic (Tuck et al. 2003, Huang 2011, see also ICCAT, Task II Catch \& Effort, T2CE, at http://iccat. int/en/accesingdb.htm), there is no doubt that discards are an important source of food for these populations. However, the benefit provided by discards is certainly not enough to offset the impact generated by the current bycatch levels on these threatened species (see Bugoni et al. 2010). An exception could be the spectacled petrel, whose global population (increasing at an annual rate of $7 \%$; Ryan \& Ronconi 2011) is concentrated in the studied region and has been down-listed to Vulnerable from Critically Endangered. Nevertheless, more research is needed to better understand the impacts of pelagic longline fishing discards in the BMC region on threatened seabird populations.

The present study demonstrated that the assemblage of seabirds associated with pelagic longliners in the slope of Uruguay and adjacent waters is highly diverse and shows great temporal variation throughout the year, which can be explained by the dynamics of the BMC, the breeding phenology, and the migration patterns of the different species. In turn, this work characterized which species use the discards made available by the fishery and how they interact. Only 14 species made significant use of dis- 
cards, coinciding with the species of albatross and petrel caught incidentally in the region. These species interact aggressively both intra-and interspecifically for access to discards. We found a dominance hierarchy related to body size, which implies that larger species have greater access to discards and baits. We conclude that the seasonality (higher captures in May to November) and composition (mainly albatrosses) of the seabird bycatch is determined by the spatiotemporal dynamics of the assemblage and by the observed pattern of interspecific interaction. Discards from various pelagic longline fleets operating in the BMC may be an important food source for at least 8 species of globally threatened albatrosses and petrels. Understanding the effect of discards on these populations could generate useful information for their conservation. Nevertheless, reducing the bycatch levels on these populations should be considered the main goal.

Acknowledgements. We thank the boat owners of the Uruguayan fleet and their crews for their continued cooperation. This work was made possible by the Programa Nacional de Observadores de la Flota Atunera Uruguaya (PNOFA), Departamento de Recursos Pelágicos, Dirección Nacional de Recursos Acuáticos (DINARA). Most of the field work was undertaken as part of 2 main programs of the 'Proyecto Albatros y Petreles - Uruguay' (PAP); the International Association of Antarctic Tour Operators (IAATO; Birds Australia, and Birdlife International's 'Save the Albatross' campaign) funded the program 'Conservation of Albatrosses and Petrels in Uruguay', and the Royal Society for the Protection of Birds (RSPB) and BirdLife International funded the program 'Albatross Task Force'. S.J. received a Scholarship from Agencia Nacional de Investigación e Innovación (ANII). We thank L. Ortega for comments on the oceanography of the study area and M. Pons for comments on data analysis. We also thank the 3 anonymous referees and the editor, whose comments and recommendations helped us to improve this paper.

\section{LITERATURE CITED}

Abraham ER, Pierre JP, Middleton DAJ, Cleal J, Walker NA, Waugh SM (2009) Effectiveness of fish waste management strategies in reducing seabird attendance at a trawl vessel. Fish Res 95:210-219

Abreu M, Jiménez S, Domingo A (2010a) Primer registro del petrel de Trindade Pterodroma arminjoniana (Procellariiformes: Procellariidae) en Uruguay. Rev Bras Ornitol 18: 240-241

Abreu M, Jiménez S, Domingo A (2010b) Registros de la pardela de cabo verde Calonectris edwardsii (Oustalet, 1883) en Uruguay (Aves: Procellariidae). Bol Soc Zool Urug 19:29-35

Acha EM, Mianzan H, Guerrero R, Favero M, Bava J (2004) Marine fronts at the continental shelves of austral South America. Physical and ecological processes. J Mar Syst 44:83-105
Alexander K, Robertson G, Gales R (1997) The incidental mortality of albatrosses in longline fisheries. Australian Antarctic Division, Kingston

Ballance LT, Pitman RL, Reilly SB (1997) Seabird community structure along a productivity gradient: importance of competition and energetic constraint. Ecology 78: 1502-1518

Bost CA, Cotté C, Bailleul F, Cherel Y and others (2009) The importance of oceanographic fronts to marine birds and mammals of the southern oceans. J Mar Syst 78:363-376

Brothers N (1991) Albatross mortality and associated bait loss in the Japanese fishery in the southern Ocean. Biol Conserv 55:255-268

Bugoni L, Furness RW (2009) Age composition and sexual size dimorphism of albatrosses and petrels off Brazil. Mar Ornithol 37:253-260

Bugoni L, Mancini PL, Monteiro DS, Nascimento L, Neves TS (2008) Seabird bycatch in the Brazilian pelagic longline fishery and a review of capture rates in the southwestern Atlantic Ocean. Endang Species Res 5:137-147

Bugoni L, D'Alba L, Furness RW (2009) Marine habitat use of wintering spectacled petrels Procellaria conspicillata, and overlap with longline fishery. Mar Ecol Prog Ser 374: 273-285

> Bugoni L, McGill RAR, Furness RW (2010) The importance of pelagic longline fishery discards for a seabird community determined through stable isotope analysis. J Exp Mar Biol Ecol 391:190-200

Croxall JP, Wood AG (2002) The importance of the Patagonian Shelf to top predator species breeding at South Georgia. Aquat Conserv 12:101-118

Cuthbert R (2004) Breeding biology of the Atlantic petrel, Pterodroma incerta, and a population estimate of this and other burrowing petrels on Gough Island, South Atlantic Ocean. Emu 104:221-228

Dawkins MS (2007) Observing animal behaviour. Design and analysis of quantitative data. Oxford University Press, Oxford

Domingo A, Bugoni L, Prosdocimi L, Miller P and others (2006) El impacto generado por las pesquerías en las tortugas marinas en el Océano Atlántico sud occidental. WWF Programa Marino para Latino América y el Caribe, San José

Favero M, Silva Rodríguez MP (2005) Estado actual y conservación de aves pelágicas que utilizan la plataforma continental Argentina como área de alimentación. Hornero 20:95-110

Favero M, Blanco G, García G, Copello S and others (2011) Seabird mortality associated with ice trawlers in the Patagonian shelf: effect of discards on the occurrence of interactions with fishing gear. Anim Conserv 14:131-139

Gandini PA, Seco Pon JP (2007) Seabird assemblages attending longline vessels in the Argentinean Economic Exclusive Zone. Ornitol Neotrop 18:553-561

Garcia CAE (1998) Oceanografia física. In: Seeliger U, Odebrecht C, Castello JP (eds) Os ecossistemas costeiro e marinho do extremo sul do Brasil. Ecoscientia, Rio Grande, p 104-106

Goetz S, Laporta M, Martínez Portela J, Santos MB, Pierce GJ (2011) Experimental fishing with an 'umbrella-andstones' system to reduce interactions of sperm whales (Physeter macrocephalus) and seabirds with bottom-set longlines for Patagonian toothfish (Dissostichus eleginoides) in the Southwest Atlantic. ICES J Mar Sci 68: 228-238 
Goni G, Wainer I (2001) Investigation of the Brazil current front dynamics from altimeter data. J Geophys Res 106: 31117-31128

- González-Solís J, Croxall J, Oro D, Ruiz X (2007) Transequatorial migration and mixing in the wintering areas of a pelagic seabird. Front Ecol Environ 5:297-301

González-Zevallos D, Yorio P (2006) Seabird use of waste and incidental captures at the Argentine hake trawl fishery in Golfo San Jorge, Argentina. Mar Ecol Prog Ser 316:175-183

González-Zevallos D, Yorio P, Caille G (2007) Seabird mortality at trawler warp cables and a proposed mitigation measure: a case of study in Golfo San Jorge, Patagonia, Argentina. Biol Conserv 136:108-116

Gotelli N, Colwell RK (2001) Quantifying biodiversity: procedures and pitfalls in the measurement and comparison of species richness. Ecol Lett 4:379-391

Griffiths AM, Siegfried WR, Abrams RW (1982) Ecological structure of a pelagic seabird community in the Southern Ocean. Polar Biol 1:39-46

Harrison P (1985) Seabirds: an identification guide. Houghton Mifflin Company, Boston, MA

Harrison NM, Whitehouse MJ, Heinemann D, Prince PA, Hunt GL Jr, Veit RR (1991) Observations of multispecies seabird flocks around South Georgia. Auk 108:801-810

Hazin FHV, Broadhurst MK, Amorim AF, Arfelli CA, Domingo A (2008) Catches of pelagic sharks by subsurface longline fisheries in the South Atlantic Ocean during the last century: a review of available data with emphasis on Uruguay and Brazil. In: Camhi M, Pikitch E, Babcock E (eds) Sharks of the open ocean. Blackwell, New York, NY, p 213-229

Hoffman W, Heinemann D, Wiens JA (1981) The ecology of seabird feeding flocks in Alaska. Auk 98:437-456

> Huang HW (2011) Bycatch of high sea longline fisheries and measures taken by Taiwan: actions and challenges. Mar Policy 35:712-720

Jiménez S, Domingo A (2009) A masked booby Sula dactylatra in Uruguay: southernmost record in the South West Atlantic. Mar Ornithol 37:275-276

Jiménez S, Abreu M, Domingo A (2008) La captura incidental de los grandes albatros (Diomedea spp.) por la flota uruguaya de palangre pelágico en el Atlántico sudoccidental. Collect Vol Sci Pap ICCAT 62:1838-1850

> Jiménez S, Domingo A, Brazeiro A (2009a) Seabird bycatch in the southwest Atlantic: interaction with the Uruguayan pelagic longline fishery. Polar Biol 32:187-196

Jiménez S, Domingo A, Márquez A, Abreu M, D'Anatro A, Pereira A (2009b) Interactions of long-line fishing with seabirds in the southwestern Atlantic Ocean, with a focus on white-capped albatrosses (Thalassarche steadi). Emu 109:321-326

Jiménez S, Abreu M, Pons M, Ortiz M, Domingo A (2010) Assessing the impact of the pelagic longline fishery on albatrosses and petrels in the southwest Atlantic. Aquat Living Resour 23:49-64

Maurer BA (1984) Interference and exploitation in bird communities. Wilson Bull 96:380-395

Neves T, Olmos F (1998) Albatross mortality in fisheries off the coast of Brazil. In: Robertson G, Gales R (eds) Albatross biology and conservation. Surrey Beatty \& Sons, Chipping Norton, p 214-219
Neves T, Vooren CM, Bugoni L, Olmos F, Nascimento L (2006) Distribuição e abundância de aves marinhas no sudeste-sul do Brasil. In: Neves T, Bugoni L, Olmos F, Vooren CM, Rossi-Wongtschowski CLB (eds) Aves oceânicas e suas interações com a pesca na região sudeste-sul do Brasil. USP-Revizee, São Paulo, p 11-35

Olmos F (1997) Seabirds attending bottom long-line fishing off southeastern Brazil. Ibis 139:685-691

Olmos F (2002) Non-breeding seabirds in Brazil: a review of band recoveries. Ararajuba 10:31-42

Olmos F, Bugoni L (2006) Agregações de aves marina associadas à pesca de espinhel-de-fundo na região sudestesul do Brasil. In: Neves T, Bugoni L, Olmos F, Vooren CM, Rossi-Wongtschowski CLB (eds) Aves oceânicas e suas interações com a pesca na região sudeste-sul do Brasil. USP-Revizee, São Paulo, p 69-81

> Olson DB, Podestá GP, Evans RH, Brown OB (1988) Temporal variations in the separation of the Brazil and Malvinas Currents. Deep Sea Res A 35:1971-1990

Onley D, Scofield P (2007) Albatrosses, petrels and shearwaters of the world. Princeton University Press, Princeton, NJ

> Oro D, Jover L, Ruiz X (1996) Influence of trawling activity on the breeding ecology of a threatened seabird, Audouin's gull Larus audouinii. Mar Ecol Prog Ser 139: 19-29

Ortega L, Martínez A (2007) Multiannual and seasonal variability of water masses and fronts over the Uruguayan shelf. J Coast Res 23:618-629

> Persson L (1985) Asymmetrical competition: Are larger animals competitively superior? Am Nat 126:261-266

- Ryan P, Ronconi RA (2011) Continued increase in numbers of spectacled petrels Procellaria conspicillata. Antarct Sci 23:332-336

Saraceno M, Provost C, Piola AR, Bava J, Gagliardini A (2004) Brazil Malvinas Frontal System as seen from 9 years of advanced very high resolution radiometer data. J Geophys Res 109:C05027. doi:10.1029/2003JC002127

Seeliger U, Odebrecht C, Castello JP (1998) Os ecossitemas costeiro e marinho do extremo sul do Brasil. Ecoscientia, Rio Grande

Sullivan BJ, Reid TA, Bugoni L (2006) Seabird mortality on factory trawlers in the Falkland Islands and beyond. Biol Conserv 131:495-504

Tuck GN, Polacheck T, Bulman CM (2003) Spatio-temporal trends of longline fishing effort in the Southern Ocean and implications for seabird bycatch. Biol Conserv 114: $1-27$

Vaske T Jr (1991) Seabirds mortality on longline fishing for tuna in southern Brazil. Cienc Cult 43:388-390

> Veit RR (1995) Pelagic communities of seabirds in the South Atlantic Ocean. Ibis 137:1-10

Wallace MP, Temple SA (1987) Competitive interactions within and between species in a guild of avian scavengers. Auk 104:290-295

> Weimerskirch H, Capdeville D, Duhamel G (2000) Factors affecting the number and mortality of seabirds attending trawlers and long-liners in the Kerguelen area. Polar Biol 23:236-249

Yorio P, Caille G (1999) Seabird interactions with coastal fisheries in northern Patagonia: use of discards and incidental captures in nets. Waterbirds 22:207-216

Submitted: March 30, 2011; Accepted: August 23, 2011

Proofs received from author(s): November 19, 2011 